INOVASI PARTISIPASI PENGANGGARAN DAERAH MELALUI MODEL PLATFORM MEDIA SOSIAL

\title{
INNOVATION OF REGIONAL PARTICIPATION BUDGETING THROUGH A SOCIAL MEDIA PLATFORM MODEL
}

\section{Lesmana Rian Andhika, Heru Nurasa, Nina Karlina, dan Candradewini Candradewini}

\author{
IImu Administrasi Fakultas IImu Sosial dan IImu Politik \\ Universitas Padjadjaran \\ Jalan Bukit Dago Utara No. 25 Bandung 40135 \\ Email: lesmana15001@mail.unpad.ac.id; heru.nurasa@unpad.ac.id; \\ nina.karlina@unpad.ac.id; candradewini@unpad.ac.id
}

Naskah diterima: 15 Oktober 2018; revisi terakhir: 20 Juni 2019; disetujui 15 Juli 2019

How to Cite: Andhika, Lesmana R., Nurasa, Heru., Karlina, Nina., Chandradewini. (2019). Inovasi Partisipasi Penganggaran Daerah Melalui Model Platform Media Sosial. Jurnal Borneo Administrator, 15 (2), 159-178. https://doi.org/10.24258/jba.v15i2.387

\begin{abstract}
The participatory budgeting process through social media has received attention in recent years, aims to increaseg citizen participation in government budgeting. The use of social media in many cases opposes the political practice assumptions of a budget lobbying to decide a specific budget post. Using conceptual article methods, we identified a participatory budgeting framework simulation using social media (Facebook, Twitter, WhatsApp, YouTube, Google+, Telegram) to provide detailed explanations of procedures or techniques, specific instructions, discuss, and describe the participatory budgeting practices determination. Therefore, it required an innovative way, academically claimed to give better budget transparency. This research resulted in some information i.e., with the participatory budgeting model through social media, the citizen can take part in the planning, decision-making, and monitoring budgets democratically. Finally, we consider the weaknesses of our knowledge, suggesting the participatory budgeting that can be tested in future research.
\end{abstract}

Keywords: Participatory Budgeting, Social Media, Citizen Participation, Innovative 


\begin{abstract}
Abstrak
Proses penganggaran partisipatif melalui media sosial telah mendapat perhatian dalam beberapa tahun terakhir, bertujuan untuk meningkatkan partisipasi masyarakat dalam penganggaran pemerintah. Penggunaan media sosial di banyak kasus menentang asumsi praktik politis anggaran dengan cara lobi untuk menentukan pos anggaran tertentu. Dengan menggunakan metode conceptual article, kami mengidentifikasi simulasi kerangka kerja penganggaran partisipatif menggunakan media sosial (Facebook, Twitter, WhatsApp, YouTube, Google+, Telegram) untuk memberikan penjelasan rinci tentang prosedur atau teknik, dan menyediakan instruksi spesifik, mendiskusikannya, dan menggambarkan penentuan praktik penganggaran partisipatif. Oleh sebab itu diperlukan cara yang inovatif, secara akademis diklaim memberikan transparansi anggaran yang lebih baik. Penelitian ini menghasilkan beberapa informasi yaitu, dengan model penganggaran partisipatif melalui media sosial, masyarakat lebih demokratis untuk ikut dalam perencanaan, pengambilan keputusan, dan pengawasan anggaran. Terakhir, kami mempertimbangkan kelemahan pengetahuan kami, menyarankan penganggaran partisipatif yang dapat diuji dalam praktik penelitian masa depan.
\end{abstract}

Kata Kunci: Penganggaran Partisipatif, Media Sosial, Partisipasi Masyarakat, Inovatif

\title{
A. PENDAHULUAN
}

Proses penganggaran selama ini dilakukan secara rutin yang disebut sebagai siklus anggaran (budgeting cycle) dari kegiatan perencanaan, penyusunan, pelaksanaan, pelaporan dan pemeriksaan. Seperangkat aturan pemerintah menjadi landasan prosedur untuk menjalankan proses anggaran pemerintah. Anggaran juga sebagai faktor pendorong pengembangan tujuan organisasi, penetapan kebijakan, alokasi sumber daya untuk mencapai tujuan (Lapsley et al., 2011; LaPlante, 2011). Di sisi lain proses penganggaran menekankan perspektif jangka panjang, dan tidak hanya menekankan keseimbangan antara pengeluaran dan pemasukan pemerintah dalam satu tahun anggaran. Selama ini proses anggaran pemerintah dilakukan dengan penggangaran berbasis kinerja (PP 21/2004).

Dari studi yang pernah dipublikasikan mengungkapkan implementasi model penganggaran berbasis kinerja masih terdapat beberapa masalah. Masalah yang sering terjadi adalah governance, human resources, dan quality information (Trenovski \& Nikolov, 2015:27-37). Dalam kasus Negara Indonesia, studi yang dilakukan oleh Widodo (2016) menemukan bahwa dalam prakteknya proses anggaran berbasis kinerja memiliki kelemahan dari penggunaan informasi kinerja dalam keputusan alokasi sumber daya masih sangat terbatas. Juga terdapat masalah untuk memastikan koordinasi, sistem pengukuran kinerja, kualitas kepemimpinan dan kemampuan dukungan manajemen. Faktanya prinsip efisiensi alokasi anggaran masih belum sesuai dengan apa yang dilaporkan oleh BPK. Terdapat permasalahan ketidakpatuhan atas pemeriksaan Laporan Keuangan Pemerintah Daerah (LKPD) Tahun 2016 antara lain kekurangan volume pekerjaan/barang senilai Rp. 416,93 miliar yang terjadi pada 453 pemda. Selain itu ditemukan belanja tidak sesuai atau melebihi ketentuan senilai Rp. 181,30 miliar, kelebihan pembayaran selain kekurangan volume senilai Rp. 127,25 miliar, serta biaya perjalanan dinas ganda atau melebihi standar yang ditetapkan senilai Rp. 52,91 miliar (BPK, 2017).

Banyak organisasi pemerintah berupaya mengembangkan penganggaran tradisional agar lebih sesuai dengan lingkungan dimana anggaran tersebut beroperasi (Anessi-Pessina, Sicilia, \& Steccolini, 2012; Rubin, 2015). Dengan demikian diperlukan usaha untuk terus 
mencari solusi masalah dari model penganggaran yang telah ada. Untuk itu mengadopsi sesuatu yang baru atau mengembangkan sesuatu yang berasal dari tempat lain sering disebut sebagai tindakan inovatif dan difusi (Rogers, 1995; Clark, Menifield, \& Stewart, 2017). Oleh sebab itu para praktisi anggaran dan akademisi mengembangkan model penganggaran inovatif dengan meningkatkan partisipasi masyarakat melalui media sosial. Tujuannya adalah sebagai alat penting untuk pemerintahan yang inklusif, akuntabel dan telah diterapkan dalam berbagai bentuk di banyak negara berkembang di seluruh dunia (Zavattaro, 2013; Gordon, 2014; Gordon, Osgood, \& Boden, 2016).

Partisipasi masyarakat dalam berbagai aktivitas pemerintah mulai mendapat perhatian ketika muncul konsep good governance (Holzhacker, Wittek, \& Woltjer, 2016:7-10). Dengan perkembangan konsep tata kelola pemerintah yang baik (Good Governance, Sound Governance, Dynamic Governance, Open Government, dan Adaptive Government) partisipasi masyarakat menjadi salah satu faktor utama dalam menjalankan pemerintahan yang baik. Misalnya open government, Wirtz dan Birkmeyer (2015:2) mendefinisikan open government sebagai a multilateral, political and social process, which includes in particular transparent, collaborative and participatory action by government and administration. Faktor politik, sejarah, sosial, dan ekonomi yang memengaruhi partisipasi masyarakat dalam sebuah negara (Cheema \& Rondinelli, 2007; Callahan, 2007). Walaupun partisipasi masyarakat masih menjadi berdebatan untuk memberikan dampak manfaat yang lebih besar dalam aktivitas pemerintah namun sisi baiknya memberi ruang kepada warga negara ikut serta mengawasi, memberikan saran, dan kritik. Pada akhirnya akan melaksanakan prinsip-prinsip akuntabilitas dan transparansi.

Salah satu bentuk partisipasi masyarakat dalam aktivitas pemerintah adalah dengan proses anggaran pemerintah melalui model penganggaran partisipatif. Model penganggaran partisipatif ini dapat mendistribusikan sumber daya secara lebih merata, mendorong pembelajaran publik, mempromosikan transparansi pemerintahan, meningkatkan akses publik terhadap pengambilan keputusan, mendapatkan akses terhadap informasi, dan memerbaiki kualitas layanan yang diberikan melalui sistem penganggaran partisipatif (Wampler, 2007; LaPlante, 2011; Kurunmaki \& Miller, 2011). Namun model ini dalam pelaksanaanya juga sering dimanfaatkan untuk membangun basis dukungan politik (Wampler, 2007:22).

Beberapa studi memberikan informasi tentang kegiatan penganggaran partisipatif, Hassett dan Watson (2003:525) melakukan studi tentang survei tahunan warga, dan dapat menjadi komponen berharga dalam proses penganggaran. Studi tersebut menemukan bahwa penggunaan survei warga negara dalam proses anggaran bertujuan untuk mengidentifikasi kebutuhan laten masyarakat yang mungkin tidak terdeteksi melalui dengar pendapat publik atau metode partisipasi warga negara lain nya (studi kasus kota Auburn dan Alabama, Amerika Serikat). Lee (2014) dari hasil penelitiannya menemukan bahwa Negara Korea mengadopsi studi kelayakan awal untuk meningkatkan efisiensi fiskal, memberikan efek terhadap keputusan anggaran untuk mencegah potensi tidak netral dari perilaku pemangku kepentingan dalam proses anggaran.

Ketika mempertimbangkan partisipasi masyarakat dalam proses penganggaran mungkin terdapat masalah yang sangat kompleks. Misalnya, masyarakat yang kurang kritis terhadap berbagai aktivitas pemerintah dapat disebabkan oleh pengetahuan yang rendah dari masyarakat pada umum nya akan mengakibatkan perencanaan dan pengambilan keputusan yang bias, dan partisipasi masyarakat berpotensi tidak mewakili mayoritas kepentingan (Bryson et al., 2012; Huang \& Feeney, 2015). Selain itu tidak hanya transparansi anggaran mendorong partisipasi publik, tetapi juga partisipasi publik 
diperlukan untuk meningkatkan transparansi anggaran (Ríos, Benito, \& Bastida, 2017:1). Partisipasi masyarakat dalam proses penganggaran pemerintah akan memberikan peluang partisipasi yang lebih tinggi dan mewakili mayoritas kepentingan masyarakat karena tidak terdapat batasan untuk memberikan usulan kebutuhan alokasi anggaran. Di sisi yang lain partisipasi masyarakat dalam proses penganggaran publik telah banyak dianjurkan oleh para ahli teori dan praktisi administrasi publik (Guo \& Neshkova, 2013:331) salah satu nya dengan menggunakan media sosial (Farazmand, 2012; Zavattaro, 2013). Khan (2017:21) menyebut, three main important components of participatory government are information socialization, participation, and communication. Model ini juga sudah dipraktikkan dibeberapa negara termasuk model penganggaran partisipatif berbasis media sosial. Penganggaran semacam ini lebih efektif untuk memprioritaskan kebutuhan program tepat sasaran (Criado, Sandoval-Almazan, \& Gil-Garcia, 2013; Medaglia \& Zheng, 2017).

Gordon, Osgood, dan Boden (2016:1) dalam studi nya menemukan, proses penganggaran melalui platform media sosial memiliki implikasi positif dalam proses penganggaran partisipatif. Temuan mereka didasarkan pada wawancara pribadi dengan tokoh masyarakat setempat yang terlibat dalam proses anggaran kota Chicago, Illinois, Louis Missouri, Boston, dan Massachusetts di Amerika Serikat. Penelitian ini didasarkan pada Model Outline: Presentation of New Concepts, Procedures, or Positions yang dikembangkan dari tulisan Watts (2011:310). Alasannya akan memberikan penjelasan rinci tentang model konseptual baru atau prosedur atau menyajikan posisi untuk membuat contoh kasus yang belum dieksplorasi dari studi sebelumnya. Penelitian ini bertujuan mengeksplorasi lebih jauh proses anggaran inovatif pemerintah daerah melalui platform media sosial sebagai wujud partisipasi masyarakat dalam proses anggaran yang digambarkan melalui sebuah simulasi. Simulasi tersebut menyajikan prosedur atau teknik, dan menyediakan instruksi spesifik, mendiskusikannya dengan kekhususan untuk menggambarkan penentuan praktik penganggaran partisipatif. Dalam simulasi juga diperhatikan banyak aspek yang diperlukan untuk memahami dan menggabungkan penggunaan platform media sosial dalam proses penganggaran partisipatif. Diantaranya sosial budaya, kebijakan sebagai landasan hukum, partisipasi, dan desain kerangka kerja penerapan media sosial. Oleh sebab itu pertanyaan yang paling relevan saat ini adalah bagaimana simulasi kerangka kerja penganggaran partisipatif melalui platform media sosial dalam proses anggaran?

\section{B. METODE PENELITIAN}

Conceptual article digunakan sebagai metode penelitian dalam penulisan artikel ini, alasan dibalik pemilihan conceptual article adalah kerangka kerja konseptual didefinisikan sebagai jaringan dari konsep terkait. Analisis kerangka kerja konseptual menawarkan prosedur teorisasi untuk membangun kerangka kerja konseptual berdasarkan metode teori. Keuntungan dari analisis kerangka kerja konseptual adalah fleksibilitasnya, kapasitasnya untuk modifikasi, penekanannya pada pemahaman, dan bukan prediksi (Gilson \& Goldberg, 2015:127-128). Selain itu, pengunaan tabel, garis, simbol, dan angka dilakukan untuk menunjukkan realitas hubungan dari berbagai sumber yang ditemukan dari beberapa temuan literatur ilmiah. Kemudian penelitian ini menggunakan pendekatan yang digerakkan oleh teori, menggunakan sejumlah teori untuk mempertahankan penyelidikan dan analisis topik yang diajukan. Kemudian Gilson dan Goldberg (2015:127-128) menegaskan bahwa artikel konseptual tidak memiliki data, karena fokus pada integrasi dan mengusulkan hubungan baru antara konstruksi beberapa teori terkait. Dengan demikian, 
tanggung jawab ilmiah berada pada pengembangan argumen logis dan lengkap untuk asosiasi dari pada menguji secara empiris.

Kemudian Watts (2011:309-311) memberikan garis besar model conceptual article yaitu 1). Model Outline: Introduction; 2). Model Outline: Review of Literature; 3). Model Outline: Presentation of New Concepts, Procedures, or Positions; 4). Model Outline: Discussion and Implications. Dalam artikel penelitian ini menggunakan Model Outline: Presentation of New Concepts, Procedures, or Positions. Adapun cara yang digunakan untuk Model Outline: Presentation of New Concepts, Procedures, or Positions adalah mereview dan penyajian ide-ide baru bersama-sama dan mungkin menyerupai, meskipun secara singkat tinjauan pustaka disajikan secara terintegrasi. Untuk mengembangkan argumentasi yang tepat, penelitian ini juga merujuk pada sejumlah kasus yang dipilih secara sengaja dan diperlakukan sebagai bukti.

\section{KERANGKA TEORI}

Pada bagian ini peneliti akan membahas kerangka teori dari pandangan para praktisi dan akademisi dari studi yang pernah dipublikasikan. Selanjutnya akan diberikan argumentasi dari beberapa kasus sebagai bahan kajian lebih lanjut untuk mengeksplorasi proses penganggaran partisipatif melalui media sosial.

\section{Proses Penganggaran Partisipatif}

Awalnya proses penganggaran partisipatif bertujuan untuk memromosikan tata kelola pemerintahan yang baik, masyarakat dilibatkan untuk pengambilan keputusan yang memengaruhi kebijakan pemerintah dari tahap perumusan sampai implementasi. Ada dua alasan mengapa proses penganggaran pemerintah melibatkan partisipatif masyarakat, pertama dengan alasan sosioekonomi, dan kedua dengan alasan institusional dan politik (Ríos, Benito, \& Bastida, 2017:1). Model penganggaran partisipatif pertama di uji coba oleh kota Porto Alegre negara Brazil pada tahun 1989. Beberapa studi telah pernah dilakukan dan menunjukkan partisipatif masyarakat dalam proses penganggaran di berbagai negara. Pinnington, Lerner, dan Schugurensky (2009:476) dalam studi nya menunjukkan, penganggaran partisipatif di kota Guelph (Kanada) dilakukan melalui metode pembelajaran partisipasi dalam penganggaran kota, hasil nya warga menjadi lebih siap menegosiasikan kendala anggaran dengan kebutuhan masyarakat, untuk keseluruhan kota. Di sisi lain dukungan lingkungan Guelph dan koalisi antara warga dan pemerintah membuka jalan baru untuk partisipasi warga dalam penganggaran pemerintahan. Kamrowska-Zaluska (2012:1996) dalam studi nya menemukan, peran partisipasi masyarakat dalam perencanaan menunjukkan evolusi anggaran partisipatif serta proses pelaksanaannya. Bila dilakukan dengan benar penganggaran partisipatif mungkin memiliki dampak yang nyata terhadap kebutuhan masyarakat sipil, membantu mendemokratisasi proses pengambilan keputusan, menciptakan dialog antara pejabat dan organisasi nonpemerintah (kasus negara Polandia).

Partisipasi masyarakat dalam model proses penganggaran sering tidak menggambarkan partisipasi masyarakat dengan adil, partisipasi masyarakat dibatasi dengan berbagai mekanisme yang menyebabkan masyarakat tidak terwakili secara luas. Namun, proses partisipatif juga berisiko dan dijalankan oleh kelompok kepentingan. Proses yang diambil mungkin terus mempromosikan elitisme dalam pengambilan keputusan pemerintah. Terdapat polarisasi yang menyebabkan hal itu terjadi akibat masih mempertahankan model penganggaran tradisional (Shah, 2007; Rubin, 2015). Ebdon dan Franklin (2006:438) memberikan elemen kunci dari penganggaran yang melibatkan 
masyarakat berkaitan dengan, 1). Environment; 2). Process Design; 3). Mechanism; 4). Goal and Outcomes.

Melalui penganggaran partisipatif, warga negara memiliki kesempatan untuk mendapatkan pengetahuan langsung tentang aktivitas dan program pemerintah, memengaruhi kebijakan pemerintah, meminta pertanggungjawaban pemerintah, dan memperkuat tata kelola inklusif pemerintah. Partisipasi warga dalam proses penganggaran mungkin saja terdapat masalah yang sangat kompleks, diilustrasikan pada Tabel 1.

Tabel 1.

Elemen Kunci Partisipasi Masyarakat Dalam Penganggaran

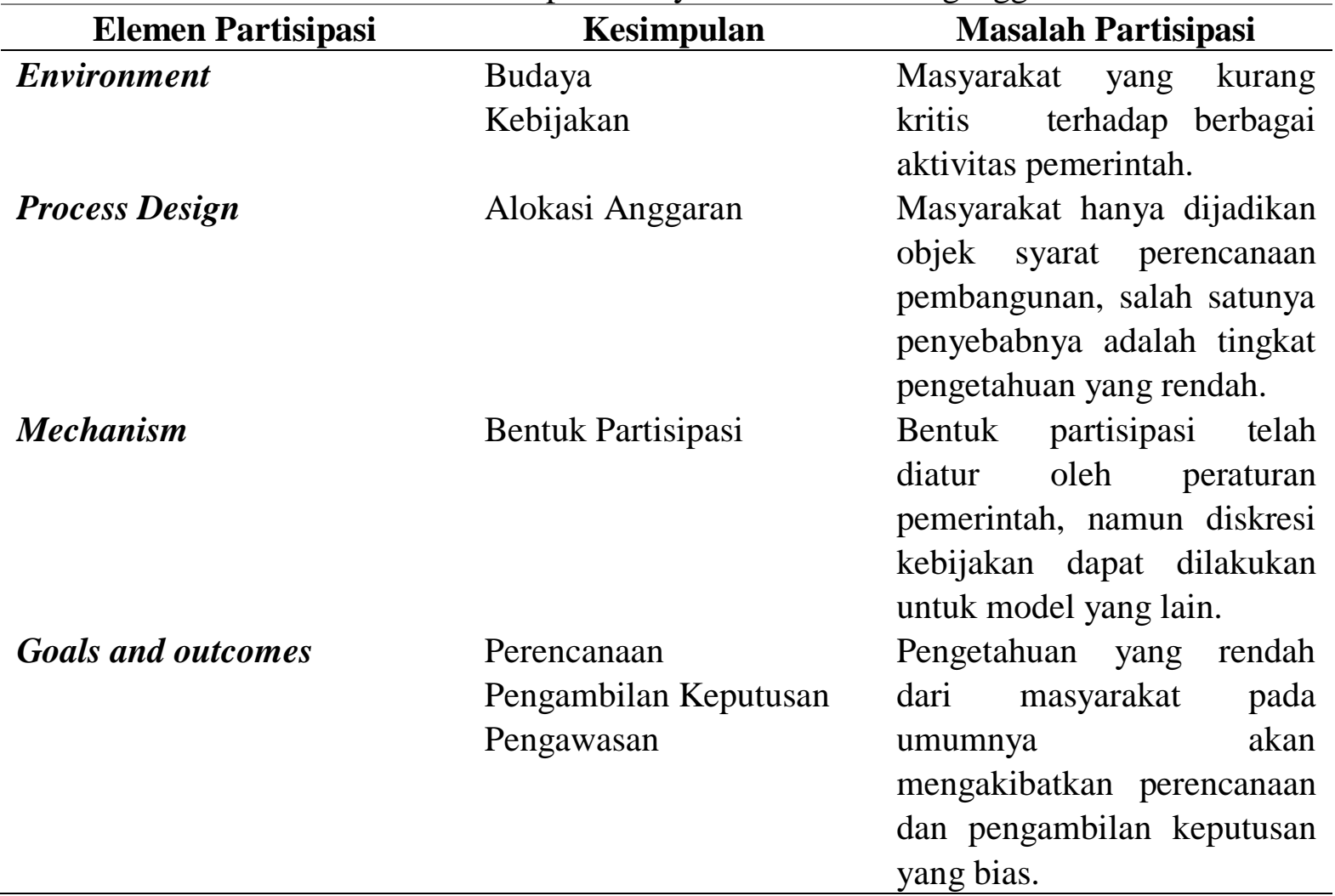

Sumber: Elaborasi dari Ebdon dan Franklin (2006)

Perbedaan bentuk pemerintahan (diasumsikan perbedaan bentuk pemerintahan demokrasi dan kerajaan), budaya memengaruhi persepsi kebutuhan partisipasi warga, dan kebijakan sering mendikte partisipasi warga untuk mendorong akses dalam aktivitas pemerintah (Ebdon \& Franklin, 2006:442). Dalam konsepsi tata kelola pemerintah yang baik partisipasi masyarakat sangat dibutuhkan untuk ikut mengawasi segala aktivitas pemerintah (Callahan, 2007; Fung, 2008). Oleh sebab itu Tjahjanulin (2012:86) dalam studi nya mencatat, di Indonesia partisipasi masyarakat masih belum terlibat langsung dalam proses penganggaran. Kendala yang dihadapi meliputi perbedaan waktu pelaksanaan proses penganggaran antara pemerintah daerah dan masyarakat, kendala waktu dalam mengikuti pelaksanaan proses penganggaran, kurang nya pengetahuan, sikap apatis masyarakat, dan fenomena bikameral (proses penganggaran pemerintah daerah di sebuah kabupaten di Wilayah Jawa Timur, Indonesia). Dengan demikian pengunaan teknologi akan sulit diimplementasikan ketika tidak diimbangi dengan pengetahuan yang cukup. Dalam kasus penelitian ini diperlukan sosialisasi untuk memobilisasi partisipasi dengan 
menggunakan teknologi (media sosial) yang didukung oleh berbagai kebijakan. Hal ini mencerminkan dengan penggunaan teknologi (media sosial) akan merubah kebiasaan masyarakat ikut serta dalam aktivitas pemerintah dengan cara yang berbeda. Diharapkan dengan partisipasi masyarakat dalam aktivitas pemerintah akan mendorong transparansi. Disisi yang lain terdapat laporan dari Komisi Informasi Pusat mencatat pada tahun 2016 terdapat 2.684 permohonan sengketa (KIP, 2017). Paling sering sengketa yang disidangkan adalah tidak transparan nya pemerintah dalam memberikan informasi kepada publik.

Elemen partisipasi process design, hal ini menyiratkan penting nya untuk mempertimbangkan waktu dan keterwakilan masyarakat dalam proses penganggaran. Karena, jika partisipasi masyarakat terlambat dalam proses perencanaan maka input anggaran akan kurang memiliki hasil yang efektif. Namun partisipasi masyarakat lebih sering ditemui pada akhir proses anggaran (Ebdon \& Franklin, 2006:439). Misal nya, komposisi belanja dalam APBD, Direktorat Jendral Bina Keuangan Daerah Kemendari mengeluarkan laporan bahwa komposisi APBD Provinsi dan Kabupaten/Kota lebih banyak diarahkan kepada belanja tidak langsung sebesar 577,91 triliun (52,9 persen), sedangkan belanja langsung sebesar 514,23 triliun (47,08 persen) dari total anggaran sebesar 1.092,15 triliun pada tahun 2016 (Dirjen Keuda, 2017). Salah satu poin dari belanja langsung adalah APBD digunakan untuk pelaksanaan urusan pemerintahan yang konkuren, penganggaran belanja langsung dituangkan dalam bentuk program dan kegiatan dalam rangka peningkatan kualitas pelayanan publik dan keberpihakan pemerintah daerah kepada kepentingan publik. Namun ini tidak berbanding lurus dengan laporan Ombudsman Republik Indonesia tahun 2015, ada sebanyak 41,59 persen atau 2.853 laporan, mengeluhkan pelayanan publik di instansi pemerintah daerah (Ombudsman, 2016:8). Arti nya bahwa desain komposisi anggaran belum merepresentasikan kebutuhan masyarakat yang lebih kongkrit untuk mendapatkan pelayanan publik. Mungkin saja pemerintah daerah tidak mendapatkan informasi yang kompleks tentang kebutuhan masyarakat yang diakibatkan oleh rendahnya partisipasi masyarakat dalam proses anggaran. Untuk itu media sosial dapat menjadi sumber mendapatkan informasi tentang kebutuhan masyarakat dengan cepat.

Elemen partisipasi mechanism, metode yang dapat dilakukan untuk memobilisasi partisipasi masyarakat dalam proses penganggaran termasuk pertemuan publik, grup diskusi, simulasi, komite, dan survei (Ebdon \& Franklin, 2006:438). Permendagri 54/ 2010 tentang Pelaksanaan Peraturan Pemerintah Nomor 8 Tahun 2008 tentang Tahapan, Tata Cara Penyusunan, Pengendalian, Dan Evaluasi Pelaksanaan Rencana Pembangunan Daerah menyebutkan bahwa musyawarah perencanaan pembangunan yang selanjutnya disingkat musrenbang adalah forum antar pemangku kepentingan dalam rangka menyusun rencana pembangunan daerah. Musrenbang merupakan representasi dari pertemuan publik untuk menyepakati RPJPD, RPJMD, dan selanjutnya dituangkan dalam bentuk RKPD. Musrenbang mengandung sejumlah masalah dihampir semua tingkat mulai desa, kecamatan dan kabupaten. Pada umumnya kegiatan yang diusulkan tidak diserap pada tingkat yang lebih tinggi, akibatnya usulan itu terkesan hanya sebagai formalitas untuk mengugurkan kewajiban, skala prioritas pembangunan menjadi alasan mengapa usulan tidak terserap. Kelemahan lain adalah ditingkat musrenbang kabupaten saluran untuk memberikan usulan, tanggapan, pengawasan kembali tidak diberikan oleh pemerintah.

Elemen partisipasi goal and outcomes, tujuan semestinya ditetapkan pada awal proses partisipasi masyarakat, dan hasil dinilai dan dibandingkan dengan apa yang diharapkan ketika tujuan ditetapkan (Ebdon \& Franklin, 2006:441). Kemudian meninjau tujuan potensial yang umum terjadi berbentuk milestone capaian ketika partisipasi 
masyarakat dalam proses penganggaran, seperti 1). Menginformasikan pengambilan keputusan; 2). Mendidik peserta dalam proses anggaran; 3). Mendapatkan dukungan untuk proposal anggaran; 4). Memengaruhi pengambilan keputusan; 5). Meningkatkan kepercayaan dan menciptakan rasa kebersamaan. Arti nya, partisipasi masyarakat dengan metode apapun dalam pengambilan keputusan dimungkinkan dan dijamin secara kontitusional. Selain diatur dalam Pasal 28 UUD 1945, hak untuk berserikat dan berkumpul juga telah dijamin dalam Pasal 28E ayat (3) UUD 1945 dan Pasal 24 ayat (1) UU 39/1999 tentang HAM. Untuk melaksanakan amanat dari Undang-Undang di atas pemerintah berupaya untuk memberikan ruang pengaduan kepada masyarakat dari permasalahan pembangunan sampai pelayanan publik melalui Ombudsman dan portal lapor.go.id.

\section{Inovasi Sektor Publik}

Secara konseptual, inovasi bercerita tentang sebuah ide/cara, praktek yang dianggap baru (Rogers, 1995:xvii). Ideal nya dari sisi tujuan dalam lingkup pemerintah, inovasi dapat menekan masalah korupsi, kolusi dan nepotisme (Klareskov \& Nikolov, 2007:44). Berkontribusi untuk meningkatkan kinerja dan efektivitas organisasi (Tohidi \& Jabbari, 2012:560). Lingkup pelayanan, inovasi dipercaya akan meningkatkan kualitas pelayanan lebih efektif dan efisien (Vries, Bekkers, \& Tummers, 2015:146). Memaksimalkan sumber daya manusia dan mengembalikan kepercayaan publik terhadap pemerintah (Alberti \& Bertucci, 2007:5). Rogers (1995:15) membagi kriteria inovasi menjadi: 1). Relative advantage, keuntungan yang didapat adalah relatif, dianggap lebih baik dari pada mengantikan yang sudah ada; 2). Compatibility, sejauh mana inovasi dianggap cocok dengan nilai-nilai yang ada, pengalaman, masa lalu, dan kebutuhan untuk mengadopsi inovasi, sebuah ide yang tidak cocok dengan nilai-nilai yang lazim dan bertentangan dengan norma-norma sosial tidak bisa diadopsi; 3). Complexity, sejauhmana tingkat kerumitan yang dihasilkan oleh sebuah inovasi, beberapa inovasi akan mudah dipahami dan diserap dengan cepat dari pada beberapa inovasi yang rumit tapi lambat untuk diterapkan; 4). Triability, sejauhmana inovasi yang saat ini dilakukan bisa bereksperimen, dikembangkan secara terbatas.

Kegiatan inovasi mencakup semua langkah ilmiah, teknologi, organisasi, keuangan dan komersial yang benar-benar mengarah atau dimaksudkan untuk melakukan inovasi (Wisdom et al., 2014; Agger \& Sorensen, 2016). Inovasi bukan hanya sekedar ide dan teknologi yang dianggap baru, namun inovasi merupakan penemuan ide-ide baru dan bagaimana menerjemahkan ide tersebut menjadi hasil yang aktual (Klimentova, 2014:292). Menggunakan media sosial dalam proses penganggaran dapat dikategorikan sebagai tindakan yang inovatif, dan model ini sangat terbatas dilakukan diberbagai tempat. Oleh sebab itu esensi data yang dihasilkan melalui media sosial berakar pada koneksi dan hubungan yang dimungkinkan antara pemerintah dan masyarakat dan pemangku kepentingan, dan merupakan salah satu aset terbesar untuk inovasi berbasis data. Bhimani, Mention dan Barlatier (2018:1) menegaskan bahwa media sosial dipandang sebagai enabler dan pendorong inovasi, dengan perspektif berbasis perilaku dan sumber daya menjadi lensa teoritis paling populer yang digunakan oleh para peneliti.

\section{Platform Media Sosial}

Kriteria media sosial bukan hanya pada tipe aplikasi namun kriteria kegunaan seperti social media is a many-to-many medium, social media is a participatory, social media is user owned, social media is conversational, social media enables openness, social media 
enables mass collaboration, social media is relationship oriented, social media free and ease of use (Khan, 2017:3). Di sisi yang lain, platform media sosial dianggap bagian dari gerakan Web. 2.0, sederhana nya platform media sosial (Facebook, Twitter, WhatsApp, Google+, Telegram, dan lain sebagainya) akan bekerja menampung berbagai usulan dari masyarakat dengan luas dan secara otomatis tidak terkait untuk membangun relasi politik bagi konstituen tertentu, penggunaan media sosial juga telah menjadi instrumen komunikasi dan perubahan (Magro, 2012; Criado, Sandoval-Almazan, \& Gil-Garcia, 2013). Mergel (2013:3) mencatat tiga kekuatan potensial utama penggunaan media sosial dalam aktivitas pemerintah yaitu, 1). Participation; 2). Collaboration; 3). Transparency.

Pertama, Participation. Konteks penganggaran dalam Wampler (2007:21) menyebut participatory budgeting is a decision-making process through which citizens deliberate and negotiate over the distribution of public resources. Untuk itu instansi pemerintah memiliki pilihan apakah akan menawarkan partisipasi secara online atau tatap muka, atau campuran dari keduanya. Keputusan ini harus dibuat setelah memertimbangkan sifat masalah, waktu, sumber daya yang tersedia, dan tujuan. Selain menghasilkan manfaat, partisipasi online dapat dilihat sebagai alat untuk memromosikan pemerintah yang terbuka dan transparan, meningkatkan kepercayaan publik, mendorong demokrasi politik, dan meningkatkan respon pemerintah terhadap kebutuhan masyarakat (Mergel, 2013:3). Sebagai contoh pemerintahan terbuka misalnya, dari 34 Provinsi, 416 Kabupaten, 98 Kota se Indonesia hanya ada 4 daerah yang menginisiasi pemerintahan terbuka (open government) yaitu Kota Banda Aceh, Jakarta, Bandung, Semarang, dan Kabupaten Bojonegoro (OGI, 2018). Tujuannya membangun keeratan dan kekuatan kepercayaan antara pemerintah dan masyarakat diberbagai elemen seperti politik, sejarah, sosial, dan ekonomi yang memengaruhi partisipasi masyarakat dalam sebuah negara (Callahan, 2007; Fung, 2008; Andhika, 2017).

Kedua, Collaboration. Kolaborasi dengan berbagai sistem dan kerjasama dengan pihak lain akan lebih menekankan keuntungan bersama (Mergel, 2013:7). Hampir semua platform media sosial dikelola oleh sektor swasta. Artinya penggunaan model seperti ini secara langsung akan memberikan keuntungan bagi swasta seperti operator jaringan dan pengelola media sosial itu sendiri. Laporan Tetra Pak Index tahun 2017 melaporkan, sekitar 132 juta pengguna internet di Indonesia dan hampir setengahnya adalah pengguna media sosial atau berkisar 40 persen (Tetra Pak Index, 2018:6). Selain itu pemerintah juga mendapatkan keuntungan dengan memermudah akses masyarakat untuk berinteraksi dalam merumuskan anggaran.

Ketiga, Transparency. Penggunaan teknologi media sosial untuk meningkatkan transparansi dan akuntabilitas dalam pemerintahan (Mergel, 2013:7). Secara tradisional, transparansi terkait dengan masalah keterbukaan informasi dari pemerintah, transparansi juga ditafsirkan sebagai fungsi pengawasan dalam aktivitas pemerintah. Transparansi erat kaitannya dengan masalah korupsi, ketika pengelolaan keuangan yang tidak transparan maka peluang untuk korupsi semakin terbuka (Ackerman, 2008:339). Laporan dari Transparency International tentang Corruption Perception Index (CPI) 2016 menempatkan Indonesia rangking 90, masih dibawah negara ASEAN lainnya seperti Singapura, Brunei, dan Malaysia. Namun laporan tahun 2017 Indonesia menempati urutan ke 96 dibawah negara Timor Leste dengan urutan 91 (Transparency International, 2018). Dibanyak negara transparansi sudah mengarah kepada penggunaan website atau istilah yang paling sering disebut sebagai transparency 2.0.

Di berbagai literatur penggunaan platform media sosial mengarah kepada inisiasi pemerintahan terbuka atau open government (Mergel, 2013:7; Khan, 2017:59). Open 
government didefinisikan sebagai tindakan dari transparansi, partisipasi, dan kolaborasi (Obama, 2009). Pemerintahan terbuka merupakan lanjutan dari tata kelola yang baik setelah good governance, saund governance, dan dynamic governance. Dalam hal pengelolaan prinsip-prinsip tata kelola, Worldwide Governance Indicators memberikan penilaian kepada Indonesia dengan beberapa kriteria governance yaitu voice and accountability (52,22), political stability and absence of violence/terrorism $(24,76)$, government effectiveness $(46,15)$, regulatory quality $(47,12)$, rule of law $(39,90)$, control of corruption $(38,46)$ (Word Bank, 2017). Sederhananya walaupun secara umum tidak menyentuh angka 50 secara keseluruhan, berbagai upaya terus dilakukan untuk menghadirkan tata kelola pemerintah yang baik.

\section{HASIL DAN PEMBAHASAN}

Pada bagian ini terlebih dahulu diuraikan praktik penganggaran partisipatif yang pernah dilakukan, kemudian akan dibahas kerangka kerja penganggaran partisipatif melalui platform media sosial berdasarkan kerangka teori yang dijelaskan pada bagian sebelumnya. Terakhir akan dibahas simulasi kerangka kerja penganggaran partisipatif melalui platform media sosial yang ditawarkan.

\section{Penganggaran Partisipatif Dalam Praktik}

Beberapa studi yang teridentifikasi menunjukkan bahwa proses penganggaran partisipatif terjadi karena ada inisiasi oleh sebuah negara. Sebagai contoh di Thailand, model partisipatif anggaran merupakan bagian dari inisiasi reformasi, ada empat model partisipasi publik dalam penganggaran yang diusulkan dengan menggunakan peran pemerintah sebagai kriteria. Keempat model ini meliputi: menginformasikan, berkonsultasi, bernegosiasi, dan memutuskan (Lorsuwannarat, 2016:10-13). Uddin, Mori, dan Adhikari $\underline{(2017: 2-3)}$ dalam penyelidikannya menemukan nilai-nilai budaya berinteraksi dengan tahapan penganggaran (tahap konsultasi bersama atau konsultasi penganggaran). Penganggaran partisipatif terjadi akibat reformasi pemerintah daerah dan diterjemahkan dalam konteks yang beragam dengan masalah penerapan pengetahuan linier dari sebuah perspektif budaya.

Dari beberapa studi di atas, dapat dipahami dalam proses penganggaran partisipatif melibatkan masyarakat dan juga nilai-nilai kearifan lokal, bertujuan untuk mendiagnosis proses musyawarah untuk mengambil keputusan secara langsung mengalokasikan anggaran pemerintah yang tepat sasaran sesuai dengan kebutuhan yang ada. Model ini selama satu dekade terakhir telah diadopsi dan tersebar pada ratusan kota di Amerika Latin, Eropa, Asia, dan Afrika. Modifikasi dilakukan dengan menyesuaikan model demokrasi lokal yang diadopsi (Pinnington, Lerner, \& Schugurensky, 2009; Gordon, Osgood, \& Boden, 2016). Adopsi desentralisasi, good governance, inisiasi reformasi beberapa pondasi alasan untuk melibatkan masyarakat dalam aktivitas pemerintah (Cheema \& Rondinelli, $\underline{2007: 140)}$.

\section{Prosedur, Proses Penganggaran Partisipatif Melalui Platform Media Sosial}

Setiap situasi dan tempat yang berlainan akan memberikan efek adopsi yang berbeda, adopsi dalam beberapa model tidak hanya menerima inovasi tapi bagaimana inovasi diintegrasikan dalam kontek yang tepat. Namun dalam level mikro perspektif perubahan, fokus adopsi bukan secara keseluruhan melainkan sebagian dari perubahan itu sendiri. Justru menggunakan berbagai cara baru (inovasi) dalam aktivitas yang tradisional memiliki tantangan tersendiri. Ketika model itu gagal, maka kesempatan berikutnya akan 
membutuhkan proses yang lebih lama. Terdapat konsekuensi yang dapat ditimbulkan seperti penambahan anggaran, bagi pemerintah menerapkan model baru dalam bentuk inovasi bukanlah hal yang baru, namun inovasi yang belum pernah dilakukan sama sekali akan memberikan kontribusi pemahaman, usaha yang lebih dalam praktik. Positif nya ketika model ini sukses akan memberikan tambahan pengetahuan dan umum nya menjadi rujukan bagi daerah lain.

Model penganggaran partisipatif menggunakan media sosial yang pernah dilakukan dapat ditemukan dari laporan Gordon, Osgood, dan Boden (2016:2-10) terlihat pada Tabel 2.

Tabel 2.

Model Penganggaran Partisipatif Menggunakan Media Sosial

\begin{tabular}{|c|c|c|c|}
\hline Description & $\begin{array}{c}\text { Social Media } \\
\text { Model }\end{array}$ & Process & Reference \\
\hline $\begin{array}{l}\text { Parcipatory } \\
\text { Budgeting; } \\
\text { Chicago, Illinois }\end{array}$ & $\begin{array}{l}\text { Twitter, Facebook, } \\
\text { Instagram, } \\
\text { YouTube, Short } \\
\text { Message Service } \\
\text { (texting), Pinterest, } \\
\text { LinkedIn, and Blogs }\end{array}$ & $\begin{array}{l}\text { 1. Neighborhood } \\
\text { Assembly Meetings } \\
\text { (October); } \\
\text { 2. Community } \\
\text { Representative } \\
\text { Meetings } \\
\text { (November } \\
\text { through March); } \\
\text { 3. Final Round of } \\
\text { Neighborhood } \\
\text { Assembly Meetings } \\
\text { to Present Project } \\
\text { Proposals to the } \\
\text { Community } \\
\text { (April); } \\
\text { 4. Election to } \\
\text { Determine the } \\
\text { Infrastructure } \\
\text { Spending } \\
\text { Priorities } \\
\text { (April/May); } \\
\text { 5. Implementation } \\
\text { and Monitoring of } \\
\text { the Winning } \\
\text { Projects (One to } \\
\text { Two Years) }\end{array}$ & $\begin{array}{c}\text { (Gordon, Osgood, } \\
\text { \& Boden, 2016) }\end{array}$ \\
\hline St. Louis, Missouri & $\begin{array}{l}\text { Twitter, Facebook, } \\
\text { Instagram, } \\
\text { YouTube, Shot } \\
\text { Message Service } \\
\text { (texting), Pinterest, } \\
\text { LinkedIn, and Blogs }\end{array}$ & $\begin{array}{l}\text { 1.Brainstorming } \\
\text { Sessions (Early } \\
\text { Fall); } \\
\text { 2.Narrowing Down } \\
\text { the List (Late } \\
\text { Fall); } \\
\text { 3.Project Expos }\end{array}$ & \\
\hline
\end{tabular}




\begin{tabular}{lll}
\hline Description & \multicolumn{1}{c}{$\begin{array}{c}\text { Social Media } \\
\text { Model }\end{array}$} & \multicolumn{1}{c}{ Process } \\
& & Reference \\
& & (Spring); \\
& & 4.Formal Proposals \\
are Put to a Vote & (April); \\
& & 5.Implementation \\
& & \\
& & \\
Bwitter, Facebook, & 1.Idea Assemblies; \\
Massachusetts & 2.Narrowing the \\
& Instagram, & List; \\
& YouTube, Shot & 3.Voting; \\
& Message Service & 4.Implementation; \\
& (texting), Pinterest, & 5.Evaluation \\
& LinkedIn, and Blogs &
\end{tabular}

Sumber: Gordon, Osgood, dan Boden (2016)

Lebih lanjut Gordon, Osgood, dan Boden (2016:4-8) mencatat, platform media sosial dalam penganggaran partisipatif pemerintah digunakan untuk proses perencanaan anggaran dan kegiatan. Menginformasikan tentang program pemerintah, membangun relasi terhadap konstituen untuk memberikan saran dan kritik sebagai upaya umpan balik formal dan informal mengenai perencanaan, dan kebijakan anggaran. Indikasi nya sebagian besar pengguna media sosial fokus pada memberikan informasi kepada masyarakat lain tentang isu-isu program pemerintah atau sebaliknya, dan memberikan kesempatan untuk bertanya dan membangun hubungan antara masyarakat dan pemerintah. Media sosial dapat digunakan untuk menghasilkan gagasan atau pendekatan baru, memecahkan masalah, memberikan akses publik yang lebih besar kepada pemimpin, mendidik masyarakat, dan mendorong kolaborasi.

Terdapat banyak kisah sukses dari penerapan platform media sosial dalam aktivitas pemerintah tapi jarang untuk proses penganggaran pemerintah. Di sisi yang berbeda, kisah sukses itu masih diwarnai dengan kehati-hatian (Shah, 2007; Magro, 2012). Hal ini dapat dipahami bahwa menggunakan platform media sosial dalam aktivitas pemerintah dapat meningkatkan partisipasi masyarakat atau bisa membuat masyarakat lebih bodoh karena kurang nya perhatian dan komitmen dari pemerintah. Mungkin ditingkat pemerintah daerah penggunaan platform media sosial kurang memberikan manfaat karena faktor pengetahuan yang tidak memadai, komitmen yang rendah, dan dukungan yang minim dari berbagai pihak terkait, tidak adanya wujud nyata dari berbagai rencana inovasi, pendidikan, dan sosialisasi. Argumentasi tersebut didukung oleh beberapa studi yang menekankan secara historis teknologi digital belum tentu memberikan manfaat karena dihalangi oleh kebiasaan tradisional yang sulit untuk diubah. Tren semacam itu dapat diubah dengan memperkuat kapasitas inovasi dengan berbagai kebijakan pemerintah, dan paling penting pemerintah dapat dan ingin menyesuaikan diri dengan perkembangan jaman yang terus cepat berubah (Magro, 2012; Mergel \& Bretschneider, 2013; Gordon, Osgood, \& Boden, 2016).

Beberapa catatan yang dapat dikemukakan dalam menyikapi penggunaan platform media sosial dalam penganggaran partisipatif masyarakat. Pertama, menetapkan sistem perencanaan anggaran yang baik, perencanaan strategis dilakukan dalam rangka merasionalisasi program tepat sasaran, harus mampu membangun identifikasi kerangka 
kerja dan hambatan untuk memroyeksikan berbagai kemungkinan tujuan yang ada. Kedua, waktu dalam satu tahun anggaran akan menggambarkan capaian disetiap bidang kegiatan penganggaran seperti perencanaan, konsultasi, pembahasan, pengesahan, pelaksanaan dan evaluasi. Sebagai contoh, penggunaan platform media sosial beroperasi secara "real time" untuk menyediakan partisipasi masyarakat dalam bentuk pertanyaan dengan sifat menyetujui atau menolak setiap program yang diusulkan. Ketiga, infrastruktur, dukungan tidak saja berasal dari masyarakat namun model pemerintahan yang tidak adiktif terhadap perubahan jaman akan sulit untuk menerapkan model ini. Terlebih tidak adanya atau kurangnya sosialisasi kepada masyarakat tentang platform media sosial akan menjadi tidak efektif karena tidak semua lapisan masyarakat mempunyai rasa tanggung jawab untuk ikut mengawasi dan berpatisipasi dalam penganggaran pemerintah, seharusnya negara menjadi inisiator untuk model ini. Keempat, eksekusi dari perencanaan dalam platform media sosial dilakukan dengan mekanisme pemungutan suara langsung oleh masyarakat sendiri, pemerintah hanya memfasilitasi. Kelima, implementasi dan evaluasi dalam model penganggaran apapun sangat penting untuk melihat capaian keberhasilan program, hal ini dikarenakan agar transparansi berbentuk pertanggungjawaban keuangan negara menjadi tolak ukur perencanaan selanjutnya.

\section{Simulasi Kerangka Kerja Penganggaran Partisipatif Melalui Platform Media Sosial}

Bila merujuk kepada penerapan proses penganggaran partisipatif menggunakan platform media sosial dalam aktivitas pemerintah yang pernah dilakukan dari beberapa literatur sebelumnya, maka simulasi penggunaan media sosial dalam proses penganggaran dideskripsikan pada Tabel 3.

Tabel 3.

Simulasi Model Penganggaran Partisipatif Menggunakan Media Sosial

\begin{tabular}{ll}
\hline \multicolumn{1}{c}{ Model } & \multicolumn{1}{c}{ Simulasi Kerangka Kerja } \\
\hline Landasan Hukum & Media Sosial \\
Model ini adalah bentuk inovasi, dan & 1.Perencanaan; \\
partisipatif (UU/23 Tahun 2014 tentang & 2.Milestone capaian; \\
Pemerintah Daerah BAB XXI pasal 381 ayat 1; & 3.Regulasi; \\
PP/58 Tahun 2005 tentang Keuangan Daerah & 4.Infrastruktur; \\
bahagian Penjelasan), dan UU/19 Tahun 2016 & 5.Pemungutan suara melalui media sosial; \\
tentang Perubahan Atas UU/11 Tahun 2008 & 6.Draf akhir perencanaan anggaran langsung \\
tentang Informasi dan Transaksi Elektronik. & atau melalui mekanisme pembahasan di \\
& legislatif untuk disahkan; \\
Facebook, Twitter, WhatsApp, YouTube, & 7.Implementasi; \\
Google+, Telegram & 8.Monitoring; \\
& 9.Transparansi dan akuntabilitas dalam bentuk \\
& pertanggungjawaban. \\
\hline
\end{tabular}

Sumber: diolah dari data sekunder (2017)

Simulasi di atas bukanlah sesuatu yang absolut untuk dilaksanakan, namun setidaknya memberikan gambaran bahwa proses penganggaran partisipatif menggunakan platform media sosial memang ada dan telah dilakukan walaupun jumlah penggunaannya terbatas pada negara tertentu dan belum menjadi tren secara universal. Keuntungan dari model peganggaran partisipatif dengan menggunakan media sosial yang telah dirancang 
sebelumnya akan memberikan banyak informasi yang diperlukan pemerintah. Selain itu informasi yang tersedia bisa digunakan untuk pengembangan tata cara mengelola menjadi lebih baik lagi. Model ini dipercaya akan meningkatkan partisipatif masyarakat dalam aktivitas penganggaran serta meningkatkan transparansi dan akuntabilitas (Gordon, Osgood, \& Boden, 2016:5). Saat ini pengunaan media sosial sangat terbatas, ada kebutuhan besar dan potensi untuk memperluas dan meningkatkan penggunaan media sosial dalam proses penganggaran untuk meningkatkan efisiensi dan transparansi. Aksesbilitas yang luas dan operasionalisasi yang mudah menjadi catatan penting dalam menggunakan media sosial.

Kausalitas yang timbul akibat dari kegiatan tersebut akan melibatkan gerakan perencanaan proses penganggaran serta memberikan kesempatan orang secara luas, terbuka untuk bergabung. Juga akan mengarah kepada kegiatan dan tindakan pengelolaan anggaran demi kepentingan umum (Anessi-Pessina, Sicilia, \& Steccolini, 2012:1-2), dan infrastuktur dalam penggunaan media sosial juga harus didukung oleh komitmen politik dan keuangan (Gordon, Osgood, \& Boden, 2016:1). Media sosial akan menghubungkan berbagai pihak, memberikan tanggapan, pertanyaan yang masuk belum tentu diberikan oleh orang yang memiliki kapasitas. Perlu memilih dari sekian banyak orang untuk mendorong transparansi pemerintah. Selain itu media sosial bisa digunakan untuk pemungutan suara langsung atas draf usulan yang buat oleh pemerintah, apakah draf itu koheren dengan yang direncanakan atau tidak. Masyarakat bisa memutuskan menerima atau merevisi ulang draf usulan itu dengan menolak dan memberikan argumentasi mengapa itu ditolak, terdapat fungsi kontrol yang dilakukan oleh masyarakat. Model partisipatif seperti ini akan membuat pemerintah lebih hati-hati untuk memilih dan memutuskan kebutuhan masyarakat.

Kesulitan yang dihadapi untuk mengimplementasikan penganggaran partisipatif melalui media sosial adalah tidak adanya kebijakan pemerintah yang mengatur secara jelas sebagai landasan hukum penggunaan media sosial untuk penganggaran. Namun sepanjang penelitian ini dilakukan berbagai pemerintah daerah di Indonesia belum melakukan penganggaran menggunakan media sosial. Walaupun hal tersebut dimungkinkan untuk dilakukan dengan menerbitkan diskresi kebijakan tingkat lokal. Keseimbangan harus tercapai antara kebijakan pemerintah, penggunaan platform media sosial dengan kebutuhan perubahan konstan, konsistensi, tepat waktu dari media sosial itu sendiri.

Lebih lanjut Khan (2017:11) menjelaskan pentingnya memahami komponen dasar media sosial dalam aktivitas pemerintah sebelum menggunakan platform, divisualisasikan pada Gambar 1.

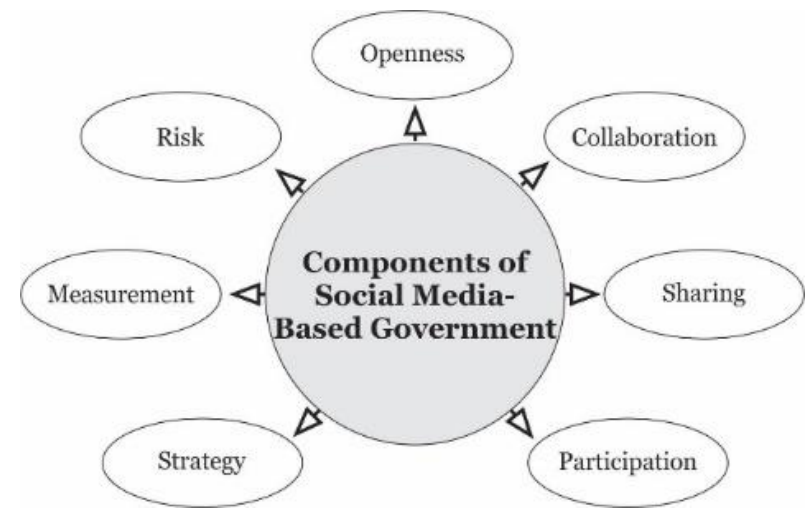

Gambar 1.

Komponen Dasar Media Sosial Dalam Pemerintah (Sumber: Khan, 2017:11) 
Strategy adalah cara untuk mengambarkan sasaran penggunaan media sosial, dan tidak semua masyarakat dapat mengetahui penggunaannya. Measurement, merupakan komponen pengukuran yang dilakukan oleh media sosial itu sendiri dengan cara melihat trafik responden terhadap satu isu kegiatan. Komponen risk, merujuk kepada resiko pengelolaan media sosial termasuk pada identifikasi risiko, penilaian, mitigasi, evaluasi, dan penilaian. Selain itu komponen openness, adalah upaya keterbukaan pada akses yang terbuka tak terbatas melalui media sosial dan Web 2.0. Collaboration, merupakan pola kerja sama dalam banyak konteks untuk tujuan bersama, termasuk pemerintah yang bekerja dengan pemerintah, pemerintah bekerja dengan warga negara, dan warga negara yang bekerja dengan warga negara. Sedangkan sharing, adalah tindakan penyebaran informasi yang bermanfaat diberbagai saluran media sosial dalam bentuk berbagai format seperti teks, video, audio sampai pada format grafik. Dan terakhir dari komponen dasar tersebut adalah participation, komponen ini mengacu pada pemberian kesempatan kepada warga untuk berpartisipasi dalam pengambilan keputusan kebijakan melalui saluran media sosial (misalnya melalui komentar dan umpan balik yang diungkapkan melalui saluran media sosial).

Selain dari pada itu Gordon (2014:1) mengingatkan bahwa penganggaran partisipatif menggambarkan potensi nilai partisipasi warga dan peran platform media sosial saat ini merupakan ekspansi dan tindakan dalam aktivitas pemerintah. Hal ini akan memerkuat argumentasi sebelumnya bahwa simulasi kerangka kerja juga memertimbangkan kemungkinan dari hasil penelitian untuk memerjelas simulasi yang diusulkan. Kemudian Gordon (2014:1) dalam studi nya merekomendasikan bahwa terdapat 3 hal penting ketika pemerintah ingin mengaplikasikan media sosial sebagai alat untuk penganggaran partisipatif. Pertama, membangun infrastruktur yang diperlukan untuk proses penganggaran partisipatif (dukungan kebijakan, sosialisasi penggunaan media sosial untuk para penggelola dan penguna dalam rangka upaya alat komunikasi dan pengembangan yang lebih luas). Kedua, tingkatkan partisipasi warga (pengguna dan pengelola harus dapat mengalihkan penggunaan platform media sosial lain jika terjadi ledakan penggunaan, penggelola dan pengguna mesti berkolaborasi mengubah peserta pasif menjadi aktif dengan memerluas sosialisasi, dan pengelola mesti memerhatikan konten pesan yang masuk). Ketiga, menilai dan meningkatkan dampak penganggaran partisipatif (pengelola mesti mengidentifikasipraktik baru melalui kegiatan penelitian, mengembangkan teknologi yang mungkin membantu menyebarkan partisipatif penganggaran lebih luas, pengguna dan pengelola mesti meminta umpan balik dari semua pemangku kepentingan).

Hasil akhir yang ingin dicapai dari model penganggaran partisipatif adalah transparansi anggaran pemeritah untuk mendukung tata kelola pemerintahan yang baik. Miller, Hildreth, dan Stewart (2017:1) memberikan argumentasi, dasar dari penganggaran partisipatif adalah proses demokrasi dimana anggota masyarakat secara langsung memutuskan bagaimana cara menghabiskan sebagian dari anggaran publik. Dalam prakteknya sering muncul berbagai kerangka kerja yang dianalisis untuk menggambarkan keterlibatan masyarakat dan interaksi warga negara secara langsung. Akibatnya, penganggaran partisipatif dapat meningkatkan kinerja pemerintah dan kualitas partisipasi demokratis (Shah, 2007; R10s, Benito, \& Bastida, 2017).

\section{E. PENUTUP}

Penganggaran berbasis kinerja dalam praktek nya masih terdapat kepentingan politis untuk menentukan pos anggaran dan penggunaan informasi kinerja dalam keputusan alokasi sumber daya masih sangat terbatas untuk menentukan kebutuhan anggaran tepat 
sasaran. Juga terdapat masalah untuk memastikan koordinasi, sistem pengukuran kinerja, kualitas kepemimpinan dan kemampuan dukungan manajemen. Proses penganggaran partisipatif melalui platform media sosial dapat memberikan kontribusi partisipasi masyarakat secara demokratis lebih luas, bagaimana masyarakat bisa memberikan tanggapan, pertanyaan, usulan terhadap isu-isu penganggaran pemerintah yang tepat sasaran berbentuk program untuk kepentingan masyarakat. Lebih lanjut penganggaran partisipatif melalui platform media sosial dapat meningkatkan transparansi, kolaborasi untuk mendukung tata kelola pemerintah yang baik. Selain itu partisipasi masyarakat diperlukan untuk mengawasi setiap aktivitas pemerintah yang demokratis. Penganggaran partisipatif memberikan banyak keuntungan, dan diyakini model ini dapat membawa masyarakat terlibat ke proses penganggaran pemerintah semakin baik. Namun banyak perkerjaan yang menuntut pemahaman selanjutnya untuk menggunakan platform media sosial dalam penganggaran partisipatif.

Keterbatasan data, fakta, sumber dukungan dari berbagai sumber sekunder kemungkinan akan menghasilkan koherensi yang bias dalam penelitian ini. Akibat lain karena model ini belum pernah dilakukan di Indonesia, ketika konsep yang diadopsi berasal dari sistem pemerintahan, budaya, ideologi negara yang berbeda bisa saja model ini tidak dapat diterapkan. Setidaknya penelitian ini dapat memberikan wawasan pengetahuan bahwa penggunaan media sosial juga bermanfaat untuk aktivitas penganggaran pemerintah.

Rekomendasi yang dapat diusulkan sebagai inti sari pembahasan pada artikel ini, bahwa penganggaran partisipatif melalui media sosial Facebook, Twitter, WhatsApp, YouTube, Google+, Telegram memiliki implikasi meningkatkan peran partisipasi masyarakat dalam proses anggaran. Selama ini proses penggangaran pemerintah daerah sering tidak sesuai dengan kebutuhan masyarakat, penetapan pos anggaran dengan mudah dapat diintervensi oleh politik melalui kolusi dengan kelompok tertentu untuk mengambil sedikit keuntungan dari aktivitas pemerintah. Awal konsep ini dikembangkan, media sosial menyediakan kebutuhan untuk melihat dan menilai apa yang semestinya dibutuhkan masyarakat. Menghindari politisasi anggaran dengan cara penerapan media sosial yang di desain untuk masyarakat melalui "kerangka kerja yang sama" perencanaan pos anggaran, voting pos anggaran untuk menyetujui draf anggaran yang dibahas antara legislatif dan eksekutif. Harapannya masyarakat dapat terus menerus mengawasi pos anggaran pemerintah dari perencanaan hingga evaluasi, menjadi salah satu tantangan kepemimpinan kontemporer pemerintah daerah dengan berbagai kebijakan pendukung, dan memerlukan studi lebih lanjut.

Bagi masyarakat model ini menjadi cara yang mudah berpartisipasi dalam aktivitas pemerintah. Terakhir untuk peneliti lain, agar dapat mengembangkan kajian platform media sosial dalam penganggaran partisipatif dari sudut pandang yang berbeda, sehingga dapat memberikan pilihan kerangka kerja yang memadai, dan pada akhir nya dapat digunakan oleh pemerintah daerah untuk melakukan penganggaran yang tepat sasaran.

\section{DAFTAR PUSTAKA}

Ackerman, S. R. (2008). Corruption and Government. International Peacekeeping, 15(3), 328-343. doi: http://dx.doi.org/10.1080/13533310802058802

Agger, A., \& Sorensen, E. (2016). Managing Collaborative Innovation in Public Bureaucracies. Planning Theory, 1-21. doi:10.1177/1473095216672500

Alberti, A., \& Bertucci, G. (2007). Innovation in Governance and Public Administration: Key Issues and Perspectives. In D. o. Affairs, Innovations in Governance in the 
Middle East, North Africa, and Western Balkans: Making Governments Work Better in the Mediterranean Region (pp. 3-12). New York: United Nations.

Andhika, L. R. (2017). Perbandingan Konsep Tata Kelola Pemerintah: Sound Governance, Dynamic Governance, dan Open Government. Jurnal Ekonomi dan Kebijakan Publik, 8(2), 87-102. doi:10.22212/jekp.v8i2.867

Anessi-Pessina, E., Sicilia, M., \& Steccolini, I. (2012). Budgeting and Rebudgeting in Local Governments: Siamese Twins? Public Administration Review, 72(6), 875884. doi:10.111/j.1540-6210.2012.02590.x.

Bhimani, H., Mention, A.-L., \& Barlatier, P.-J. (2018). Social Media and Innovation: A Systematic Literature Review and Future Research Directions. Technological Forecasting \& Social Change, 1-19. doi:10.1016/j.techfore.2018.10.007

BPK. (2017). BPK Temukan 2.525 Ketidakpatuhan yang Berakibat Kerugian senilai Rp1,13 triliun dalam LHP LKPD. Siaran Pers Badan Pemeriksa Keuangan, Biro Humas dan Kerja Sama Internasional BPK-RI, Jakarta.

Bryson, J. M., Quick, K. S., Slotterback, C. S., \& Crosby, B. C. (2012). Designing Public Participation Processes. Public Administration Review, 73(1), 23-34. doi:10.111/j.1540-6210.2012.02678.x

Callahan, K. (2007). Citizen Participation: Models and Methods. International Journal of Public Administration, 30(11), 1179-1196. doi:10.1080/01900690701225366

Cheema, G. S., \& Rondinelli, D. A. (2007). Decentralizing Governance: Emerging Concept and Practice. Washington D.C: Brookings Institution Press.

Clark, C., Menifield, C. E., \& Stewart, L. M. (2017). Policy Diffusion and Performancebased Budgeting. International Journal of Public Administration, 1-7. doi:10.1080/01900692.2016.1278384

Criado, J. I., Sandoval-Almazan, R., \& Gil-Garcia, J. R. (2013). Government Innovation Through Social Media. Government Information Quarterly, 30(4), 319-326. doi:10.1016/j.giq.2013.10.003

Dirjen Keuda (2017, September 20). Postur APBD 2016. online http://keuda.kemendagri.go.id/datin/index/1/2016 diakses tanggal 27 September 2018

Ebdon, C., \& Franklin, A. L. (2006). Citizen Participation in Budgeting Theory. Technology, Communication, Collaboration, 66(3), 437-447. doi:10.1111/j.15406210.2006.00600.x

Farazmand, A. (2012). The Future of Public Administration: Challenges and Opportunities A Critical Perspective. Administration \& Society, 44(4), 487-517. doi:10.1177\%2F0095399712452658

Fung, A. (2008). Citizen Participation in Government Innovations. In S. Borins, Innovations in Government: Research, Recognition, and Replication (pp. 52-70). Washington D.C: Brookings Institution Press.

Gilson, L. L., \& Goldberg, C. B. (2015). Editors' Comment: So, What Is a Conceptual Paper? Group \& Organization Management, 40(2), 127-130. doi:10.1177/1059601115576425

Gordon, V. (2014). Participatory Budgeting: Ten Actions to Engage Citizens via Social Media. Washington, DC: IBM Center for the Business of Government.

Gordon, V., Osgood, J. L., \& Boden, D. (2016). The Role of Citizen Participation and the Use of Social Media Platforms in the Participatory Budgeting Process. International Journal of Public Administration, 40(1), 1-12. doi:10.1080/01900692.2015.1072215 
Guo, H. (., \& Neshkova, M. I. (2013). Citizen Input in the Budget Process: When Does It Matter Most? The American Review of Public Administration, 43(3), 331-346. doi:10.1177/0275074012443588

Hassett, W. L., \& Watson, D. J. (2003). Citizen Surveys: a Component of the Budgetary Process. Journal of Public Budgeting, Accounting \& Financial Management, 15(4), 525-541. doi:10.1108/JPBAFM-15-04-2003-B003

Holzhacker, R. L., Wittek, R., \& Woltjer, J. (2016). Decentralization and Governance in Indonesia. Switzerland: Springer International Publishing AG.

Huang, W.-L., \& Feeney, M. K. (2015). Citizen Participation in Local Government Decision Making: The Role of Manager Motivation. Review of Public Personnel Administration, 36(2), 188-209. doi:10.1177/0734371X15576410

Kamrowska-Zaluska, D. (2012). Participatory Budgeting in Poland - Missing Link in Urban Regeneration Process. Procedia Engineering, 161(1), 1996-2000. doi:10.1016/j.proeng.2016.08.792

Khan, G. F. (2017). Social Media for Government: A Practical Guide to Understanding, Implementing, and Managing Social Media Tools in the Public Sphere. Singapore: Springer Nature.

KIP. (2017). Laporan Tahunan 2016 Komisi Informasi Pusat. Jakarta: Komisi Informasi Pusat.

Klareskov, V., \& Nikolov, D. (2007). Eleven Innovations in Governance in the Middle East, North Africa, and Western Balkans: A Synopsis. In D. o. Affairs, Innovations in Governance in the Middle East, North Africa, and Western Balkans: Making Governments Work Better in the Mediterranean Region (pp. 41-52). New York: United Nations.

Klimentova, S. (2014). Innovation in the Public Sector: Is it Measurable. Studies in Managerial and Financial Accounting, 28, 289-315. doi:10.1108/S1479351220140000028021

Kurunmaki, L., \& Miller, P. (2011). Regulatory Hybrids: Partnerships, Budgeting, and Modernising Government. Management Accounting Research, 22(4), 220-241. doi:10.1016/j.mar.2010.08.004

LaPlante, J. M. (2011). Seven Habits of Unsustainable Budget Building: A State Policy Perspective. Journal of Public Budgeting, Accounting \& Financial Management, 23(2), 215-267. doi:10.1108/JPBAFM-23-02-2011-B004

Lapsley, I., Midwinter, A., Nambiar, T., \& Steccolini, I. (2011). Government Budgeting, Power and Negotiated Order. Management Accounting Research, 22(1), 16-25. doi:10.1016/j.mar.2010.10.009

Lee, S. (2014). The Impact of the Korean Preliminary Feasibility Study on Budgetary Decisions. A Thesis Submitted for the Degree of Doctor of Philosophy, The University of Birmingham, Birmingham.

Lorsuwannarat, T. (2016). Public Participation in Budgeting: The New Path of Budget Reform in Thailand. International Journal of Public Administration, 40(5), 1-16. doi:10.1080/01900692.2015.1126730

Magro, M. J. (2012). A Review of Social Media Use in E-Government. Administrative Sciences, 2(1), 148-161. doi:10.3390/admsci2020148

Medaglia, R., \& Zheng, L. (2017). Mapping government social media research and moving it forward: A framework and a research agenda. Government Information Quarterly, 34(3), 496-510. doi:10.1016/j.giq.2017.06.001 
Mergel, I. (2013). Social Media in the Public Sector: A Guide to Participation, Collaboration, and Transparency in the Networked World. San Francisco: John Wiley \& Sons.

Mergel, I., \& Bretschneider, S. I. (2013). A Three-Stage Adoption Process for Social Media Use in Government. Public Administration Review, 73(3), 390-400. doi:10.1111/puar.12021

Miller, S. A., Hildreth, R. W., \& Stewart, L. M. (2017). The Modes of Participation: A Revised Frame for Identifying and Analyzing Participatory Budgeting Practices. Administration \& Society, 1-28. doi:10.1177/0095399717718325

Obama, B. (2009, January 21). Transparency and Open Government: Memorandum for the Heads of Executive Departments and Agencies. Retrieved from whitehouse: http://obamawhitehouse.archives.gov/the-press-office/transparency-and-opengovernment

OGI. (2018). Di Daerah Mana Saja Praktik Pemerintahan Terbuka Diimplementasikan? online http://www.opengovindonesia.org/practice diakses tanggal 27 Agustus 2018

Ombudsman. (2016). Laporan Tahunan 2015. Jakarta: Ombudsman Republik Indonesia.

Pinnington, E., Lerner, J., \& Schugurensky, D. (2009). Participatory Budgeting in North America: The Case of Guelph, Canada. Journal of Public Budgeting, Accounting \& Financial Management, 21(3), 454-483. doi:10.1108/JPBAFM-21-03-2009-B005

Ríos, A.-M., Benito, B., \& Bastida, F. (2017). Factors Explaining Public Participation in the Central Government Budget Process. Australian Journal of Public Administration, 76(1), 48-64. doi:10.1111/1467-8500.12197

Rogers, E. M. (1995). Diffusion of Innovations (4th ed.). New York: The Free Press.

Rubin, I. (2015). Past and Future Budget Classics: A Research Agenda. Public Administration Review, 75(1), 25-35. doi:10.1111/puar.12289.

Shah, A. (2007). Parcipatory Budgeting. In A. Shah, Overview (pp. 1-20). Washington, DC: The World Bank.

Tetra Pax Index. (2018). Tetra Pak Index Report 2017. Switzerland: Tetra Pak Index.

Tjahjanulin, D. (2012). Public Participation in Budgeting Process at Local Government in Indonesia. Russian Journal of Agricultural and Socio-Economic Sciences, 12(60), 86-90. doi:10.18551/rjoas.2016-12.11

Tohidi, H., \& Jabbari, M. M. (2012). Innovation as a Success Key for Organizations. Procedia Technology, 1(1), 560-564. doi:10.1016/j.protcy.2012.02.122

Transparency International. (2018). Corruption Perseption Index, online https://www.transparency.org/news/feature/corruption_perceptions_index_2017 diakses tanggal 27 Agustus 2018

Trenovski, B., \& Nikolov, M. (2015). Cost-Benefit Analysis of Performance Based Budgeting Implementation. CEA Journal of Economics, 10(20), 5-43.

Uddin, S., Mori, Y., \& Adhikari, P. (2017). Participatory Budgeting in a Local Government in a Vertical Society: A Japanese Story. International Review of Administrative Science, O(0), 1-16. doi:10.1177/0020852317721335

Vries, H. d., Bekkers, V., \& Tummers, L. (2015). Innovation in the Public Sector: A Systematics Review and Future Research Agenda. Public Administration, 94(1), 146-166. doi:10.1111/padm.12209

Wampler, B. (2007). A Guide to Participatory Budgeting. In A. Shah, Parcipatory Budgeting (pp. 21-54). Washington, DC: The World Bank. 
Watts, R. E. (2011). Developing a Conceptual Article for Publication in Counseling Journals. Journal of Counseling \& Development, 89(3), 308-312. doi:10.1002/j.1556-6678.2011.tb00094.x

Widodo, T. (2016). Performance Based Budgeting: EvidenceFrom Indonesia. Disertasi University of Birmingham, Birmingham. Online: http://etheses.bham.ac.uk/7501/ diakses tanggal 05 Mei 2018

Wirtz, B. W., \& Birkmeyer, S. (2015). Open Government: Origin, Development, and Conceptual Perspective. International Journal of Public Administration, 00(0), 116. doi:10.1080/01900692.2014.942735

Wisdom, J. P., Chor, K. H., Hoagwood, K. E., \& Horwitz, S. M. (2014). Innovation Adoption: A Review of Theories and Constructs. Adm Policy Ment Health, 41(4), 480-502. doi:10.1007/s10488-013-0486-4

Zavattaro, S. M. (2013). Social Media in Public Administration's Future: A Response to $\begin{array}{lllll}\text { Farazmand. Administration \& Society, } & 45(2), & 242-255 .\end{array}$ doi:10.1177/0095399713481602

Word Bank. (2017). Worldwide Governance Indicators 2015, online http://info.worldbank.org/governance/wgi/\#reports diakses tanggal 27 Agustus $\underline{2018}$

Peraturan Perundang-Undangan

Undang-Undang Dasar Republik Indonesia Tahun 1945

Undang-Undang Negara Republik Indonesia Nomor 39 Tahun1999 tentang Hak Asasi Manusia.

Undang-Undang Negara Republik Indonesia Nomor 23 Tahun 2014 tentang Pemerintah Daerah

Undang-Undang Negara Republik Indonesia Nomor 19 Tahun 2016 tentang Perubahan Atas Undang-Undang Negara Republik Indonesia Nomor 11 Tahun 2008 tentang Informasi dan Transaksi Elektronik

Peraturan Pemerintah Nomor 21 Tahun 2004 Tentang Penyususnan Rencana Kerja Anggaran Kementrian Negara/Lembaga Republik Indonesia

Peraturan Pemerintah Nomor 58 Tahun 2005 tentang Keuangan Daerah

Peraturan Menteri Dalam Negeri Nomor 54 Tahun 2010 tentang Pelaksanaan Peraturan Pemerintah Nomor 8 Tahun 2008 tentang Tahapan, Tata Cara Penyusunan, Pengendalian, Dan Evaluasi Pelaksanaan Rencana Pembangunan Daerah 